\title{
Przydatność perspektywy biograficznej w badaniu grup dyspozycyjnych
}

https://doi.org/10.19195/2083-7763.10.6

\section{Abstrakt}

Artykuł jest próbą oceny przydatności wywiadów biograficznych w badaniu funkcjonowania grup dyspozycyjnych. Przedstawiono w nim argumenty ogólnoteoretyczne na rzecz stosowania perspektywy biograficznej w tego rodzaju analizach oraz ich ilustrację empiryczną odwołującą się do konkretnego wywiadu. Rekomendowana perspektywa pozwala pozyskać dane trudne do uzyskania w inny sposób, pozwala zneutralizować niektóre trudności związane z badaniem w trudnym terenie badawczym i dostarcza materiału do formułowania płodnych hipotez.

Słowa kluczowe: badania biograficzne, grupy dyspozycyjne

Celem mojego artykułu jest ocena przydatności perspektywy biograficznej $\mathrm{w}$ analizie społecznych uwarunkowań, jak i analizy specyfiki funkcjonowania grup dyspozycyjnych jako elementu systemów bezpieczeństwa. Przedstawione dalej spostrzeżenia wynikają z refleksji zarówno nad wyzwaniami, jak i rezultatami prowadzonego przeze mnie przez kilka lat badania empirycznego.

\section{Mocne strony perspektywy biograficznej}

Refleksja ogólnometodologiczna pozwala wskazać kilka potencjalnych silnych punktów stosowania w badaniu socjologicznym perspektywy biograficznej.

Może pojawić się pytanie, $w$ jakim stopniu związana $\mathrm{z}$ badaniem biograficznym procedura metodologiczna może być przydatna w badaniu funkcjonowania grup 
dyspozycyjnych i pod jakimi względami typ pozyskiwanych danych może wzbogacić wiedzę w tej kwestii. Na rzecz tego istnieją argumenty o różnej wadze.

1. Jednym $z$ nich jest kwestia dostępu do terenu badań. Badaczom organizacji formalnych dobrze jest znana trudność z uzyskaniem stosownych pozwoleń, które osobom z zewnątrz instytucji umożliwiłyby samo zbieranie danych, ale także pozwoleń wyznaczających zakres i treść możliwych do pozyskania danych. Trudności takie szczególnie wyraźne są na przykład w wypadku wojska i policji, gdzie określony poziom niejawności wewnętrznej organizacji i sposobów działania jest warunkiem skutecznego działania. Jakościowe techniki mogą być mniej inwazyjne w życie instytucji niż sondaż, zwłaszcza w formie ankiety audytoryjnej. Wywiad prowadzony na dużo mniejszej próbie pozwala w pewnym stopniu ominąć formalne ograniczenia. Zgodę na wywiad trzeba uzyskać od rozmówcy, nie od instytucji.

2. Można także natrafić w organizacjach formalnych, a w szczególności w takich, gdzie jedną z funkcji jest formowanie pożądanej mentalności jej członków na barierę oficjalnej wersji sytuacji. Taka wersja jest mniej lub bardziej wyraźnie formułowana i oczekuje się jej przynajmniej werbalnego uznania. Zatem w warunkach kontroli przez przełożonych, rzeczywistej lub wyobrażonej, będzie ona komunikowana niezależnie od tego, czy odpowiada rzeczywistości.

3. Biograficzny charakter wywiadu (jakościowy) wprowadza perspektywę „egocentryczną" - ujawnia punkt widzenia jednostki. To czasami bywa poczytywane za wadę i określane mianem subiektywizmu. Jednocześnie jednak daje właśnie dostęp do znaczeń. Znajomość subiektywnego punktu widzenia jest jednakże pożyteczna, a w świetle niektórych założeń teoretycznych wręcz konstytutywna dla prowadzenia wartościowego badania socjologicznego.

4. Biograficzny wywiad może być narzędziem wprowadzającym do badania wymiar diachroniczny - pozwala bada procesy.

5. Przyjęta orientacja metodologiczna prowadzi do szczególnego rodzaju kompleksowości oglądu działającej jed nostki - ujawnia się ona w złożonym zespole relacji z innymi (w szczególności na tle relacji rodzinnych). Relacje te stanowią co najmniej „,znaczący kontekst” dla wewnątrzorganizacyjnego funkcjonowania, jednak często obszar zawierający czynniki w określony sposób to działanie determinujący.

6. Inny rodzaj kompleksowości wiąże się z wprowadzeniem perspektywy diachronicznej. Zaangażowanie $\mathrm{w}$ grupę dyspozycyjną zazwyczaj jest tylko ograniczonym czasowo momentem życia jednostki. Przyjęcie szerszej perspektywy czasowej pozwala uchwycić znaczenie i konsekwencje tego zaangażowania dla całości lub dalszego ciągu życia. Ta kwestia jest raczej trudna do ujęcia na drodze prostych badań przekrojowych realizowanych w określonym czasie.

7. Wywiady takie dają dostęp i rejestrują oryginalny język rozmówców, którego cechy formalne, leksyka, frazeologia, obrazowanie itp. stanowią bogatą warstwę informacyjną. 
Nie znaczy to oczywiście, że omawiane jakościowe wywiady są panaceum na trudności, które starają się jakoś złagodzić. Uniknięcie pewnych formalnych ograniczeń, jeśli chodzi o dostęp do terenu badań, nie oznacza, że uzyskanie zgody na wywiad od potencjalnego rozmówcy (nawet jeśli nie jest on już czynnym członkiem grupy dyspozycyjnej, będąc na przykład emerytem) jest łatwe. Nie przesądza też, czy uda się badaczowi dotrzeć do informatorów kluczowych. Faktem jest jedynie mniejsza inwazyjność procedury w rzeczywiste funkcjonowanie grupy.

Większe prawdopodobieństwo dotarcia poza oficjalną wersję sytuacji nie oznacza też, że członkowie grup dyspozycyjnych nie mogą w określonych sytuacjach i w przypadku określonych problemów badawczych stosować na przykład autocenzury.

\section{Opis badania własnego}

Rozważania teoretyczno-metodologiczne mają swoją wartość, ale naprawdę przekonujące byłoby prześledzenie wyników konkretnych przedsięwzięć empirycznych posiłkujących się tą metodologią. Niestety, nie są mi bliżej znane badania tego typu.

Pozwolę zatem kwestię tę zilustrować odwołaniem do badania własnego, które jako całość nie było poświęcone grupom dyspozycyjnym, ale doświadczenia przedstawicieli tych grup pojawiły się w nim w istotny sposób. Było to mianowicie badanie, którego najogólniejszym celem było udokumentowanie, ale też w miarę możliwości bardziej teoretyczne ujęcie dość burzliwego okresu w dziejach naszego kraju wyznaczonego symbolicznymi datami: od roku 1989, w którym odbyły się pierwsze częściowo wolne wybory parlamentarne i powstał pierwszy niekomunistyczny rząd, do roku 2004, gdy Polska wstąpiła do Unii Europejskiej.

Zmiana społeczna interesowała mnie ze szczególnego punktu widzenia, który w centrum uwagi lokuje indywidualne losy mieszkańców regionu w badanym okresie. Nie chcę w tym miejscu wchodzić w dyskusję, w jakim stopniu przyjęta perspektywa ujmuje zjawiska konstytutywne dla życia społecznego ${ }^{1}$. Jeśli jednak przyjąć wizję życia społecznego wyrastającą z szeroko rozumianego interakcjonizmu, rdzeniem procesów społecznych są interakcje społeczne. Zarówno procesy przekształcania się struktur społecznych, ekonomicznych, społecznych, jak i trajektorie jednostkowego życia są określonymi aspektami strumienia

${ }^{1} \mathrm{~W}$ tej kwestii można przedstawić spectrum stanowisk: od poglądu, że życie społeczne jest — jak pisał Florian Znaniecki w Przedmowie do Młodego pokolenia chłopów Józefa Chałasińskiego — „niczym innym, jak właśnie częściowo uporządkowaną syntezą wielu żyć osobistych” (1938, s. VII), po stanowisko, że biografie jednostek stanowią jedynie epifenomen dynamiki ponadjednostkowych struktur. 
oddziaływania ludzi na siebie. Losy życiowe składają się na dynamiczny aspekt życia codziennego.

W świetle przyjętej perspektywy teoretycznej i orientacji na przebieg życia poszczególnych jednostek przyjęłam założenie, że dowolny okres historyczny, a zatem proces zmiany społecznej prezentuje się jednostkom przede wszystkim poprzez zdarzenia życiowe. $W$ tym kontekście podstawowym celem badania stało się opisanie zdarzeń życiowych będących udziałem jednostek wchodzących w skład badanej zbiorowości w przyjętym okresie oraz dostarczenie przesłanek do oceny, w jakim stopniu oraz w jaki sposób zdarzenia te dokumentują (wskaźnikują, wyrażają, egzemplifikują) proces zmian społecznych. Pozwoliło to pokazać, $\mathrm{w}$ jakim stopniu i w jaki sposób przeobrażenia systemowe wpisywały się w jednostkowe biografie ${ }^{2}$.

Zdarzenie $\mathrm{w}$ życiu zostało przyjęte zatem jako podstawowa kategoria w badaniu. Jest ono zawsze czyjeś w tym sensie, że jego uchwycenie wymaga uwzględnienia sposobu, w jaki definiuje je doświadczający go podmiot.

Szeroko uznanym sposobem dotarcia do subiektywnych definicji jest akt komunikacji, czyli w praktyce badawczej wywiad.

Mając świadomość ograniczeń wskazywanych we współczesnych dyskusjach dotyczących statusu wywiadu jako procedury badawczej ${ }^{3}$ oraz ogólnych założeń leżących u podłoża różnych jego form, poszukiwałam takiej techniki, która pozwoli w najbardziej optymalny sposób zbliżyć się do realizacji tu nakreślonego celu badawczego. Zdecydowałam się na formułę oral history ${ }^{4}$.

Dość oczywistą przesłanką, która skłoniła mnie do wykorzystania elementów oral history w badaniach, jest fakt, że dotyczyły one przeszłości i ramy cza-

${ }^{2}$ Przydatnego określenia zdarzenia życiowego dostarcza Daniel Bertaux, charakteryzując elementy opowieści o życiu: „Znajdziemy tam elementy opisu stanów: każdemu momentowi drogi życiowej odpowiada pewien stan fizyczny i psychiczny osoby badanej, jej „osobowość”, ale także siły życiowe, pewien stan silnych relacji interpersonalnych, jej sieci relacji, status i sytuacja społeczna (praca, zasoby, mieszkanie, majątek, sytuacja rodzinna i obiektywne „szanse/możliwości życiowe”). Wszystko to, co zmienia znacząco przynajmniej jeden z tych trzech stanów, stanowi wydarzenie; i odwrotnie — każde wydarzenie na drodze życiowej zmienia przynajmniej jeden z tych stanów. Są to w szczególności działania podejmowane przez jednostkę, mające na celu zmianę któregoś z tych trzech stanów, w sensie jego oczekiwanej poprawy" (D. Bertaux, Analiza pojedynczych przypadków (au cas par cas), przeł. A. Trąbka, [w:] Metoda biograficzna w socjologii. Antologia tekstów, red. K. Kaźmierska, Kraków 2012, s. 312).

Aktorzy zatem nie są jedynie biernymi odbiorcami tego, co im w życiu się wydarza — samo zdarzenie może polegać na ich określonej aktywności. W tym sensie przekształcenia możliwe do opisania w innym planie jako zmiany (albo stabilność) szerszych struktur są konstytuowane przez jednostkowe działania lub/i realizowane poprzez włączanie ich w strumień działań (na przykład jako warunki lub konsekwencje tychże).

3 Zob. np. A. Fontana, J.H. Frey, Wywiad. Od neutralności do politycznego zaangażowania, [w:] Metody badań jakościowych, t. 2, red. N.K. Denzin, Y.S. Lincoln, Warszawa 2009.

${ }^{4}$ Handbook of Oral History, red. T.L. Charlton, L.E. Myers, R. Sharpless, Lanham 2008.

Forum Socjologiczne 10, 2020

(C) for this edition by CNS 
sowe zjawiskom będącym przedmiotem zainteresowania wyznacza szczególny wycinek historii naszego społeczeństwa.

Nie bez znaczenia był dobrze sprecyzowany i opisany aspekt realizacyjny wywiadów oral history, włączając w to uzyskiwanie zgody, opracowywanie wywiadu, wskazówki dotyczące rejestracji i transkrypcji.

Jednak dodatkowe racje przemawiały na rzecz wykorzystania formatu oral history do zbierania danych. Przede wszystkim w moim odczuciu nadaje on sytuacji wywiadu szczególnego rodzaju zewnętrzne ukierunkowanie. Zaprezentowany rozmówcom cel badania jako gromadzenie informacji o losach mieszkańców regionu w określonym wycinku czasu sugeruje (w zamierzony sposób) koncentrację opowieści raczej na relacjach z innymi (także na kontaktach z instytucjami) niż na życiu wewnętrznym i abstrakcyjnych poglądach. Podnosi to prawdopodobieństwo pozyskania przede wszystkim wiedzy epizodyczno-narracyjnej w odróżnieniu od semantyczno-konceptualnej ${ }^{5}$.

Z punktu widzenia założeń mojego badania dotarcie do wspominanych sytuacji i epizodów ma kluczowe znaczenie.

Założyłam, że przyjęcie formuły oral history będzie ukierunkowywało rozmówców głównie na zdarzenia „obiektywne”, a „biograficzność” wywiadu na zdarzenia, w które byli uwikłani osobiście. Twierdzę, że taki wywiad nie jest typową, codzienną rozmową naturalną, ale też nie jest interakcją całkowicie sztuczną. Składanie sprawozdania z własnego życia nie należy do zdarzeń zupełnie wyjątkowych i niezwykłych.

Ponieważ nie było moim celem dokonywanie ilościowych uogólnień z podzbioru na liczniejszą populację osób (losów życiowych czy też zdarzeń), proste statystyczne ujęcie reprezentatywności jako zgodności rozkładów zmiennych w próbie i w zbiorowości generalnej nie miało tu zastosowania. Bardziej adekwatne wydawało się dążenie, aby w całości procesu badawczego zrealizować postulat reprezentatywności typologicznej.

\section{Elementy doświadczenia przedstawicieli grup w świetle badania własnego}

Materiału empirycznego dostarczyło ponad czterysta wywiadów swobodnych zbieranych od 2004 do 2008 roku z mieszkańcami województwa zachodniopomorskiego, przy czym interesowały mnie doświadczenia osób znajdujących się w tym wieku, który wiąże się z najwyższym poziomem aktywności (przynajmniej potencjalnym) na rynku pracy i w życiu publicznym. W doborze rozmówców

${ }^{5}$ Jak argumentuje Uwe Flick: „ta pierwsza dotyczy w większym stopniu sytuacji, ich kontekstu i rozwoju, ta druga - bardziej abstrakcyjna, ogólna i wyrwana z kontekstu — operuje pojęciami". Rozróżnienie to opiera się na modelach pamięci stworzonych przez psychologię poznawczą (Jakość w badaniach jakościowych, Warszawa 2011, s. 101-102). 
chodziło o osoby, które bezpośrednio, w różnych wymiarach życia mogły konfrontować się z przemianami w otaczającej ich rzeczywistości.

Specyfika dobranych rozmówców przesądziła, że obszar zawodowy - oprócz spraw rodzinnych - był dla uczestników badania podstawowym źródłem osobistych doświadczeń i dotyczyły go w dużej mierze (a czasami wyłącznie) zebrane w wywiadach narracje. W większości wypadków relacje te pozwalały wskazać podstawową (albo przynajmniej dominującą wśród kilku innych) dla danego rozmówcy formę działalności.

W doborze rozmówców nie byli wskazywani przedstawiciele konkretnych grup zawodowych.

Okazało się, że porównywane z sobą wywiady można na dość ogólnym i formalnym poziomie pogrupować $\mathrm{w}$ wiązki na podstawie elementarnej działalności rozmówców. Na tej zasadzie wyłonił się więc kompleks doświadczeń osób podejmujących (prowadzących) własną działalność gospodarczą, a następnie osób, których główna działalność polegała na pracy fizycznej oraz pracowników umysłowych. Szybko też okazało się, że płeć ma znaczenie w ramach podstawowej działalności i można stwierdzić zróżnicowane doświadczenia życiowe kobiet i mężzzyzn.

W zebranym materiale zaznaczył się także specyficzny kompleks doświadczeń będących udziałem przedstawicieli służb mundurowych.

Nie będę bardziej szczegółowo przedstawiać wyników badania, odsyłając do mającej się ukazać książki ${ }^{6}$, ale także dlatego, że odnoszą się one do konkretnej sytuacji historycznej. Tym niemniej ogólnie wyliczę podstawowe rezultaty.

1. Badanie pokazało silne uwikłanie doświadczeń przedstawicieli grup dyspozycyjnych (zdecydowanie większe niż innych kategorii rozmówców) w kontekst ideologiczny i polityczny, a także sposoby tego uwikłania - funkcjonowanie tychże kategorii badanych (grup) silnie powiązane jest $\mathrm{z}$ kwestiami władzy; badane zmiany wyrażały się w szczególnego rodzaju dezideologizacji służby w niektórych wymiarach, jednakże związek z kontekstem władzy pozostawał bardzo znaczący.

2. Odsłoniła się duża rola wyrazistej kultury organizacyjnej związanej z grupami dyspozycyjnymi (milicją, wojskiem) jako modelu, za pomocą którego rozmówcy ujmowali zmiany rzeczywistości społecznej (z dużą w tym rolą opozycyjnych kategorii porządku i chaosu) - rozmówcy mieli skłonność do traktowania uporządkowanego i poddanego regulaminom działania instytucji jako przykładu prawidłowego i normalnego funkcjonowania świata społecznego.

3. Inna niż biograficzna metoda raczej nie pozwoliłaby ujawnić szerokiego zakresu doświadczeń zawodowych jako zasobu wykorzystywanego poza służbą; po części związane jest to z faktem istnienia określonych przywilejów

${ }^{6}$ M. Fiternicka-Gorzko, Od czerwca do maja. Transformacja systemowa $w$ doświadczeniach mieszkańców województwa zachodniopomorskiego [w druku]. 
emerytalnych skutkujących przejściem na emeryturę $\mathrm{w}$ wieku produkcyjnym; z punktu widzenia jednostki okres życia zawodowego poza służbą okazywał się dość długi; w wypadku omawianego czasu historycznego omawiany zasób wykorzystywany był w szczególności w:

— działalności gospodarczej na własny rachunek (w szczególności handlu)

— tu w szczególności spożytkowywany był kapitał społeczny nabyty podczas służby przez byłych milicjantów);

— aktywności w strukturach samorządu terytorialnego;

- „cywilnych” grupach dyspozycyjnych (straż leśna).

4. Powszechność doświadczenia for malnej weryfikacji, sprawdzenie przez czynnik władzy, które miało charakter pewnego rodzaju całościowej oceny ukazywało to ponownie uwikłanie doświadczeń badanych osób w kontekst funkcjonowania władzy;

5. Wywiady pokazały wyraźne pojawianie się „pokoleń” w organizacji - konkretne formy podziału na „ludzi starych” $i$ „ludzi nowych”.

6. Tylko całościowy wywiad pozwalał zbadać dynamikę relacji rodzinnych (na przykład w rodzinach osób wyjeżdżających na misje).

Wspomniane wyniki odnoszą się do konkretnego momentu historycznego, ale w mojej ocenie omawiana perspektywa badawcza może dostarczyć danych, które trudno pozyskać w inny sposób.

\section{Przykład empiryczny}

Pozwolę sobie zilustrować to przykładem wywiadu, w którym jest problematyka wymieniona $\mathrm{w}$ pierwszym $\mathrm{z}$ wyliczonych punktów, ale też można $\mathrm{w}$ nim uchwycić pewne ogólniejsze rysy subiektywnego postrzegania służby oraz jej konsekwencje życiowe.

Wybrałam do tego celu historię sześćdziesięcioletniego ${ }^{7}$ emerytowanego policjanta, wcześniej milicjanta. Włodzimierz (imię zmienione) wychował się na wsi pegeerowskiej.

Jak [...] sobie przypomnę tych moich rodziców, to oni tylko... No, nic nie mieli, praktycznie nic! [...] No, jak przyjechało nieraz to kino [objazdowe], to wszyscy lecieli jak... jak nie wiem do czego! [...] Wszyscy musieli być na tym kinie. [...] Bo nic innego nie było. Tylko jakieś tam [...] jabole. I tylko robota od czwartej rano, tam czy od trzeciej do obory, na pole - i tyle tylko widzieli! [...] Czyli nic nie widzieli! I tak samo, i ja nic nie widziałem! [09-0027] ${ }^{8}$

${ }^{7}$ Wiek podany na moment przeprowadzenia wywiadu.

${ }^{8}$ Numer w nawiasie oznacza pozycję wywiadu w zbiorze danych. Pierwsze dwie cyfry oznaczają datę przeprowadzenia wywiadu (tu 2009), pozostałe — jego numer identyfikacyjny w roczniku. Przyjmuję też następującą regułę prezentowania danych: sformułowania rozmówcy są wyróżnione kursywą, dłuższe wypowiedzi wyróżnione z zasadniczego tekstu poprzez zmniejszenie czcionki i wcięcie. 
Rozmówca skończył szkołę zawodową w pobliskim miasteczku. Zapisał się do Związku Młodzieży Wiejskiej - został przewodniczącym koła związku w swojej miejscowości - za swoją dużą zasługę dla społeczności uznaje zwieńczone powodzeniem starania o uruchomienie pod koniec lat sześćdziesiątych XX wieku finansowanego przez PGR klubu wiejskiego. („Tam gdzieś teraz [jest] kaplica" - wyjaśnia prowadzącemu wywiad). Po odbyciu służby wojskowej rozmówca złożył podanie o przyjęcie do Milicji Obywatelskiej, które rozpatrzono pozytywnie. Włodzimierz dostał skierowanie do hotelu milicyjnego w Szczecinie i rozpoczął pracę. „Awans, skok społeczny” - tak określa swoją sytuację — diametralna zmiana $\mathrm{w}$ porównaniu $\mathrm{z}$ „wegetacją $\mathrm{w}$ pegeerze”. Mógł wtedy zacząć myśleć o założeniu rodziny. Po ślubie mieszkał cztery lata u teściowej. Po jakimś czasie, gdy miał już dwójkę dzieci, otrzymał mieszkanie „przez komendę wojewódzką — przyśpieszenie i tak dalej - to też był [...] bardzo duży plus".

Praca mu się podobała.

Byłem takim zwykłym patrolowym [...] na ulicy. Chociaż mnie się też tam podobało z tego względu, że miasto dobrze poznałem. Jak ja przyszedłem, ze wsi chłopak, i do takiego dużego miasta, no to co ja tam znałem? Nic nie znałem, a takie poznanie [...] od podszewki [...] każdej ulicy, każdego zaułka — to wszystko się poznało - i to [...] procentowało w całej [...] pracy. [09-0027]

Jeździł też na „wyjazdy za bandziorami z bronią”, ale przede wszystkim:

No to czynności ogólne wtedy milicjanta, [...] no, normalne. [...] Musi złapać złodzieja, musi kierowców ukarać, musi ukarać przechodnia... [09-0027]

Kiedy trzeba, potrafi „zdzielić”, choć jak twierdzi, wolał zawsze używać perswazji, „bo to człowieka można uszkodzić, [...] nie wiadomo, kto jaką chorobę ma - [...] różnie bywa".

Cechą służby jest ścisłe podporządkowanie się poleceniom przełożonych: „Rozkaz, [...] czyli nie ma, że nie, tylko musi być to zrobione. Nie ma dyskusji”. Towarzyszy temu manipulacyjny stosunek do ludzi - na tym, między innymi polega praca: „jeśli byłeś cwańszy, to tego obywatela można było tak przekręcić, że... tak zrobić, że on nawet [...] nie wiedział, kiedy się znalazł, gdzie i co".

Do pracy, jak zapewnia rozmówca, „trzeba mieć smykałkę”. Z biegiem czasu dołącza się do niej doświadczenie.

Już tak zostaje to we krwi, że człowiek oczy to ma tak uwrażliwione na złodziei, [...] że po prostu widzi kto, jak się zachowuje. [...] I mówię do syna: [...] „Patrz, idzie złodziej!”, „Niemożliwe!” Ja mówię: „Zaraz zobaczysz”. I stanęli żeśmy z boku i go tak obserwowali. [...] Kobieta stała do lady, miała z tyłu torebkę. A on jej tą torebkę otworzył i rękę jej tak wkłada... Już miał do połowy rękę włożoną, ale złodziej też ma siódmy zmysł. Obejrzał się, że my go obserwujemy, wyciągnął rękę i - poszedł! [09-0027]

Oprócz tych czysto policyjnych aspektów pracy istotnym elementem jest jej wymiar polityczny, czego praktyczny wyraz stanowiła przynależność do PZPR. Włodzimierz zapisał się do partii. Jak większość rozmówców uznaje za konieczne 
wytłumaczenie tego faktu. To tłumaczenie odbywa się przez podkreślanie wewnętrznego dystansu do niego (,ja do partii należałem, ale to tylko to, żeby składki płacić, a nie czułem... wewnętrznie jakiejś potrzeby”). Jedynie „ci wyżej”, na przykład „mój sekretarz”, może się utożsamiali. Jednocześnie Włodzimierz podkreśla, że na partyjnych „patrzyło się inaczej” - miało to znaczenie na przykład przy staraniach o mieszkanie. Akces do partii jest też widziany przez niego jako warunek utrzymania się „,w tej robocie”, którą wykonywał.

Różne formy „tłumaczenia się” z przynależności do partii (ale także podkreślania faktu nieprzynależności) można znaleźć $\mathrm{w}$ wielu wywiadach $\mathrm{z}$ przedstawicielami służb mundurowych. Stosunkowo często spotykany w tych opowieściach jest opis rytualnego niemal aktu „darcia” lub „wyrzucania do kosza”, w każdym razie fizycznego niszczenia albo legitymacji partyjnej („książeczki”), albo druków deklaracji przystąpienia do partii podsuwanych przez funkcjonariuszy partyjnych. Ze względu na teatralizację tłumaczenia takie nie brzmią specjalnie wiarygodnie. Włodzimierz, który odcina się wyraźnie od ideologii głoszonej przez PZPR, jednocześnie opisuje swoje zażarte spory ze szwagrem podczas rodzinnych spotkań.

Z rodziną [...] to były stosunki bardzo dobre. Chociaż przy spotkaniu żeśmy się dużo sprzeczali na tematy właśnie tej „Solidarności” i tak dalej. Bo z różnych środowisk cała rodzina jest. [...] I to jedni $\mathrm{z}$ „Solidarności” byli, ja byłem w partii i jak żeśmy się spotkali, no to żeśmy troszeczkę się sprzeczali na różne tematy. A nawet dochodziło do [...] takich sesji, że żeśmy się brali za łby trochę, [...] żeśmy się tam trochę poszarpali. [09-0027]

Pewnym usprawiedliwieniem gwałtowności sporów ze szwagrem było to, że odbywały się one podczas rodzinnych zjazdów wokół beczki z piwem, ale sam fakt ich występowania zdaje się dowodzić jednak, że ideologia nie należała do kwestii całkowicie obojętnych.

Jednakże w dużej liczbie przypadków zwłaszcza żołnierze zawodowi demonstrowali przekonanie, że służba wyposażała ich $\mathrm{w}$ wiedzę niedostępną zwykłym członkom społeczeństwa, w szczególności dotyczącą potencjalnych zagrożeń w sytuacji konfliktu społecznego w Polsce. Tym zagrożeniem było przede wszystkim „,50 dywizji radzieckich za granicą Polski, [...] NRD, [...] Czesi - wszystkie te jednostki [...] zmobilizowane i gotowe do wejścia". Świadomość ta dostarczała szczególnego rodzaju uprzywilejowania poznawczego, ale budziła niepokój.

Myśmy sobie zdawali sprawę, mieliśmy wyraźne sygnały, wiedzieliśmy, co grozi i baliśmy się, no bo po prostu [...] każdy rozsądny człowiek, który zdawał sobie sytuację z zagrożenia, powinien się bać. [09-0044]

Ważny obszar doświadczeń Włodzimierza odsłaniają jego relacje dotyczące udziału w konfrontacjach z demonstracjami ulicznymi w latach osiemdziesiątych. W udramatyzowany i narracyjny sposób przedstawia epizody walk z agresywnym, niebezpiecznym tłumem ciskającym kostką brukową i zrzucającym z dachów kamienic na milicjantów "całe, nawet sklejone takie cegły”. Sytuacje te dostarczały „adrenaliny”, ale „nie było wesoło”. Co więcej, „ja nie wiem, czy bym nie został 
zabity, żeby nie kolega, bo z tyłu mnie facet zaszedł i zdzielił" jakimś niebezpiecznym narzędziem. Jedncześnie jednak strony walki te dawały sposobność wykazania się hartem ducha.

Mam dosyć taką psychikę mocną, [...] nie przeżywałem tego, jak niektórzy koledzy, [...] którzy z kibla nie wychodzili. Ich żołądek nie wytrzymywał, nie wytrzymywał organizm, że siedział w kiblu, ze strachu się wypróżniał [...] aż do niemożliwości, jak słyszał, że idziemy na ulicę i walczyć tam gdzieś. [09-0027]

Konsekwencją między innymi tych konfrontacji jest długotrwałe wyraźne odczuwanie dystansu pomiędzy milicją a „społeczeństwem”. We wspomnieniach $\mathrm{z}$ lat osiemdziesiątych, ale także w myśleniu dotyczącym późniejszych spraw, czuć dość wyraźnie „retorykę zagrożenia” charakteryzującą język propagandy czasów stanu wojennego. Okres gwałtownej fazy konfliktu minął, ale pozostały „takie rzeczy", jak:

Straszenie, znaczy naszych rodzin, nie? Milicjantów, nie? Że przyjdziemy, was tu... zrobimy to czy tamto i tak dalej, takie... Pukanie do drzwi w nocy, podrzucanie kartek z różnymi tam tekstami, że to zrobimy, to tamto... W piwnicy znajdowałem kartki. [...] Takie drobne rzeczy... [...] Raczej się nie bałem aż tak o rodzinę, chociaż strach jest zawsze, bo to nie wiadomo kto, komu co do głowy strzeli, nie? [...] Ale w razie większego zagrożenia miały nasze rodziny być ewakuowane do jednostki wojskowej tutaj. [09-0027]

Doświadczenia z pracy przyczyniają się do szczególnego poczucia wyższości wobec innych służb mundurowych. Włodzimierz opowiada, jak już po przekształceniu milicji w policję z rozformowywanych jednostek wojskowych zgłaszali się kandydaci na policjantów. „Był taki okres, że mogli przechodzić bezpośrednio stopniami ze wszystkim do policji”, ale byli „zieloni”, nie mieli „o niczym pojęcia”.

Żołnierz, to wiadomo, na rozkaz też - tu też, ale inna specyfika. Ja to mówię, że żołnierze to mają tak, jak konie klapki na... [09-0027]

Zmiana, która nastąpiła po roku 1989, na różne sposoby jest przez Włodzimierza bagatelizowana: „co mogło się zmienić wielkiego dla przeciętnego zjadacza chleba? [...] To tam wielce się nie zmieniło, bo egzystować jakoś trzeba”. Musiał jednak, aby pracować dalej w policji, przejść weryfikację. Uważa to za „bezbolesny” zabieg.

Ja w tym tumulcie tego [...] zamieszania narodowego i tak dalej, no po prostu przeszedłem nad tym wszystkim. [...] Ja się tam nie przejmowałem tym wszystkim, bo [...] praktycznie mnie to aż tak mocno nie dotyczyło. Bałem się tylko tyle, że w trakcie mojej służby - różne tam dochodziły głosy — że zmieni się... emerytury się zmienią, znaczy się wysługa lat i tak dalej... Takie różne pierdoły. [09-0027]

Można było „rzucić mundur”, ale co wtedy? „Odwrócić się i iść — tylko gdzie?”, bo jakby się poszło do jakiegoś zakładu „i powiedziało, że tu i tu się pracowało to nie wiem, co by było. Bo to różni ludzie byli".

Jeśli chodzi o samą weryfikację — „to konkretnie nie wiem, jak to się odbywało”. Nikt mu tego nie powiedział. „Przeglądali po prostu człowieka teczki, cały przebieg służby...” Nie wiadomo „kto i tak dalej nas weryfikował”. Jakaś „góra”. 
Tak analizując [...] swoją służbę — ja nic nie przeskrobałem, nikomu... nikogo nie zabiłem, nikogo nie uszkodziłem, tak że po prostu nie mógł żyć i tak dalej. I to jest to, że ja nie miałem nic za koszulą, jak to się mówi, takiego trefnego. [09-0027]

Ktoś musi wykonywać tę robotę na ulicy — nawet jeśli kiedyś „szli żeśmy przeciwko robotnikom, tym co walczyli na ulicy" - to przecież dzisiaj jest to samo - robotnicy palą opony na ulicach w protestach przeciwko „solidarnościowym” rządom i policja musi wyjść przeciwko nim. „Jak nająłeś się za psa, to szczekaj jak pies". Po weryfikacji został dyspozytorem w jednostce.

Jednak w roku 1993 Włodzimierz odszedł z policji wraz z dwoma kolegami, „bo już miałem dość tego wszystkiego”, mimo że nie przysługiwała mu, jak mówi, pełna emerytura. Przełożony zachęcał, żeby „dopracował” do pełnej emerytury, „ale człowiek już myślał o czym innym”. Jednym z powodów, choć być może nie najważniejszym, była chęć wyjazdu „myślałem wyjechać trochę za granicę i popracować za granicą, zobaczyć, jak tam jest”. Rozmówca przez rok pracował w Niemczech i wrócił. Zaczął żałować decyzji odejścia od służby przed uzyskaniem pełni praw emerytalnych.

I to mnie troszeczkę tak zgnębiło, ale [...] się podniosłem z tego wszystkiego, bo ruszyłem do pracy z powrotem. Że do innej - to innej, ale do pracy przede wszystkim pomiędzy ludzi [09-0027].

Jednym z zasobów wyniesionych z pracy w milicji jest umiejętność „czytania przepisów".

I już [z powodu rzekomego pogorszenia wzroku] nie czytam teraz książek. [śmieje się] A przede wszystkim czytam przepisy. I trzymam się tego, że umiem zajrzeć, bo mnie tego nauczyła milicja, kodeksu karnego, kodeksu wykroczeń, tego wszystkiego. [...] I umiem zajrzeć. [...] I umiem się podeprzeć wszystkim, gdzie tylko by nie było. To ja poczytam sobie, poszukam mnie nikt nie załatwi! Pójdę do pracodawcy i mu powiem: proszę bardzo: tu jest tak, a tak, ja mi pan coś nie tego, to ja potrafię napisać. [...] Człowiek musi o swoje walczyć. [09-0027]

Jednak swoją sytuację wyraźnie kontrastuje z okresem za komuny także od strony finansowej.

Wtedy ja miałem poczucie takiego mocnego stabilnego życia. A w tej chwili to jest takie, jak liść na wietrze. Cały czas dygocze. I nie wiadomo, kiedy spadnie. Nie wiadomo. On jeszcze mocny jest, trzyma się, zielony, ale może spaść. [...] Nie wiadomo, kiedy ten wiatr większy przyjdzie. [...] Cały czas słyszymy: kryzys, kryzys, kryzys [09-0027]

W narracji Włodzimierza zmiany zachodzące w świecie społecznym zdają się w niewielkim stopniu odbijać na instytucji, w której był zatrudniony - a przynajmniej wyraźnie o tym nie mówi, choć należy pamiętać, że prawdopodobnie nie bez powodu zwolnił się z policji. Zasadnicza zmiana polegała na uwolnieniu się od ideologicznego uwikłania, które Włodzimierz bagatelizował. Głębszym doświadczeniem było, jak się wydaje, doświadczenie podziału między „posiadającymi/reprezentującymi władzę” i „nieposiadającymi władzy”. Sam postrzega się jako „szeregowego przedstawiciela aparatu władzy”, misja zaś polegająca na łapaniu 
złodziei, karaniu kierowców i pieszych zdaje się niezależna od jakichkolwiek uwikłań w sferę polityki.

Na podstawie tego przykładu można wyliczyć skrótowo kilka charakterystycznych rysów służby odsłaniających się z punktu widzenia rozmówcy, które mogą być punktem wyjścia do analizy porównawczej i bardziej kompleksowych rozważań dotyczących na przykład kwestii, czy są to warunki konieczne tej formy działalności w społeczeństwie ujawniające specyfikę dyspozycyjności ${ }^{9}$ w życiu społecznym:

1. służba postrzegana jako forma awansu (umożliwiająca awans społeczny), rodzaj wyróżnienia;

2. korzyści poznawcze (poczucie wewnętrznego rozwoju) związane z podjęciem służby;

3. wypracowanie poczucia biegłości, profesjonalizmu, pojawienie się złożonych umiejętności na poziomie „nawykowym”;

4. określony typ struktury władzy;

5. ideologiczne (lub szerzej: odwołujące się do „wysokich” wartości) uzasadnienie służby nadające jej nawet w przypadku dezideologizacji charakter analogiczny do powołania;

6. uprzywilejowanie poznawcze („widzenie więcej” niż nieprofesjonaliści);

7. dystans wobec „społeczeństwa” — rodzaj wyodrębnienia;

8. korzystna pozycja w układzie porównawczym (tu: przewagi nad innymi formami służby);

9. pozyskiwanie zasobów indywidualnych możliwych do skapitalizowania poza służbą.

\section{Bibliografia}

Bertaux D., Analiza pojedynczych przypadków (au cas par cas), przeł. A. Trąbka, [w:] Metoda biograficzna w socjologii. Antologia tekstów, red. K. Kaźmierska, Kraków 2012.

Handbook of Oral History, red. Charlton T.L., L.E. Myers, R. Sharpless, Lanham-New York-Toronto-Plymouth 2008.

Fontana A., Frey J.H., Wywiad. Od neutralności do politycznego zaangażowania, [w:] Metody badań jakościowych, t. 2, red. N.K. Denzin, Y. Lincoln, Warszawa 2009.

Flick U., Jakość w badaniach jakościowych, przeł. P. Tomanek, Warszawa 2011.

Maciejewski J., Grupy dyspozycyjne - analiza socjologiczna, Wrocław 2012.

\footnotetext{
${ }^{9}$ J. Maciejewski, Grupy dyspozycyjne - analiza socjologiczna, Wrocław 2012.
} 


\section{Usefulness of the biographical perspective in the study of dispositional groups}

\section{Summary}

The article is an attempt to assess the usefulness of biographical interviews in the study of dispositional groups' functioning. General theoretical arguments for the use of a biographical perspective and their empirical illustration referring to a specific interview are presented. The recommended perspective allows us to obtain data which are difficult to be found in any another way, neutralizes some of the obstacles associated with 'difficult research fields', and provides material for formulating fertile hypotheses.

Keywords: biographical research, dispositional groups 